\title{
Environmental factors associated with biodiversity and the occurrence of rare, threatened, thermophilous species of aquatic beetles in the anthropogenic ponds of the Masurian Lake District
}

\author{
Joanna Pakulnicka · Andrzej Górski • Aleksander Bielecki
}

Received: 25 June 2013/Revised: 15 July 2014/Accepted: 29 July 2014/

Published online: 8 August 2014

(C) The Author(s) 2014. This article is published with open access at Springerlink.com

\begin{abstract}
This paper presents the results of an analysis of species richness (expressed as number of species), biodiversity (the $H^{\prime}$ index) and synecological structure of communities of aquatic beetles living in clay and gravel pits. It evaluates the analyzed habitats in terms of the influence of water physical and chemical parameters on the characteristics of beetle assemblages. The assessment of beetle communities was performed from the point of view of ecology and nature conservation. The analyzed physical and chemical parameters of water as well as the presence of certain species, mainly rheophiles, indicate very weak eutrophication of the ponds. The parameters which most significantly distinguish gravel pits from clay pits are specific conductivity, $\mathrm{HCO}_{3}{ }^{-}, \mathrm{SO}_{4}{ }^{2-}$ and $\mathrm{Cl}^{-}$. The PCA analysis, however, suggests that the abundance and species richness as well as the biodiversity of beetles living in the analyzed ponds were most closely correlated with temperature and with $\mathrm{NH}_{4}-\mathrm{N}$, total $\mathrm{N}$ and the $\mathrm{BOD}_{5}$ of water. The analyzed ponds proved to be very attractive habitats populated by numerous species, including rare, threatened (listed in the Polish Red Book of Species) and termophilous ones, or organisms valuable to Polish wildlife for other reasons. They include two species rare in Poland-Hydrochus ignicollis and Ochthebius hungaricus, one species fully protected in Poland-Hydrophilus aterrimus (VU), as well as Haliplus fulvicollis (VU) and Gyrinus caspius (EN). The findings are important for the preservation of biodiversity, both locally and on a scale surpassing the region, a conclusion which highlights the value of anthropogenic ponds such as clay pits
\end{abstract}

Communicated by Eliska Rejmankova.

Electronic supplementary material The online version of this article (doi:10.1007/s10531-014-0774-7) contains supplementary material, which is available to authorized users.

J. Pakulnicka $(\bowtie) \cdot$ A. Górski

Department of Ecology and Environmental Protection, University of Warmia and Mazury in Olsztyn, Łódzki Square 3, 10-727 Olsztyn, Poland

e-mail: joanna.pakulnicka@uwm.edu.pl

A. Bielecki

Department of Zoology, University of Warmia and Mazury in Olsztyn, Oczapowskiego Str. 5, 10-718 Olsztyn, Poland 
and gravel pits, in the ecological landscape and implies that they deserve an adequate protection in order to sustain their function.

Keywords Biodiversity - Communities of water beetles - Chemical parameters . Anthropogenic ponds - The red list - Threatened species - Thermophilous species

\section{Introduction}

Anthropogenic ponds, formed in pits made by the excavation of mineral resources, have become a crucial component of the hydrographic network (Pakulnicka 2008). Their role is increasingly important as the degradation of the aquatic environment progresses due to water contamination, eutrophication and, above all, a lower level of groundwater, which is responsible for the disappearance of many small water bodies, particularly kettle lakes. Anthropogenic ponds turn into habitats settled by communities of invertebrates, which are extremely rich and diverse with respect to species and synecology (Barnes 1983; Donath 1980; Stöckel 1983; Kognitzki 1988; Ohnesorge 1988; Spitzenberg 1988; Ott 1995; Carl 1997; Sternberg 1997; Trockur 1997; Weihrauch 1998; Xylander 1999; Buczyński 1999; Buczyński and Pakulnicka 2000; Wimmer and Sprick 2000; Kowalik and Buczyński 2003; Lewin and Smoliński 2006; Pakulnicka 2008; Lenda et al. 2012). These organisms often originate from natural aquatic habitats, like lakes, bogs, rivers and even streams (Carl 1997). They include rare species, threatened with extinction and subjected to different forms of nature conservation or included on Red Lists drawn up by many countries (Buczyński and Pakulnicka 2000; Lewin and Smolinski 2006; Pakulnicka 2008; Lenda et al. 2012). The special role of anthropogenic ponds in maintaining species richness and preserving many species of invertebrates was implied, for example, by Wildermuth and Krebs (1983); Ohnesorge (1988); Collinson et al. (1995); Ott (1995); Carl (1997); Sternberg (1997); Geißler-Strobel et al. (1998); Buczyński (1999); Williams et al. (2004); Pakulnicka (2008). Their observations are supported by the results of studies on other groups of organisms, e.g. those belonging to zooplankton (Trahms 1972; Lipsey and Malcolm 1981) or to birds (Catchpole and Tydeman 1975; Hudoklin and Sovinc 1997). It can be claimed that ponds formed in excavation pits assume, at least to some extent, the ecological functions of natural ponds, counteracting certain unfavorable changes in the natural landscape.

Many authors emphasize the considerable influence of physical and chemical parameters of habitats on species richness, abundance and diversity of communities of living organisms (Trahms 1972; Barnes 1983; Lewin and Smolinski 2006; Eyre et al. 1992; Jurkiewicz-Karnkowska 2011). This observation applies to aquatic beetles as well (Winfield Fairchild et al. 2000; Bosi 2001; Eyre et al. 1992). Water beetles are a fundamental component of the fauna dwelling in various aquatic habitats (Foster et al. 2009; Foster and Eyre 1992; Menetrey et al. 2005; Giora et al. 2010a, b; Pakulnicka and Nowakowski 2012). The fauna of water beetles is ecologically varied and consists of 4 synecological components, understood as groups of species sharing common habitat preferences (Pakulnicka 2008). Those are: eurytopic species, argillotrophic species, tyrphophilous species and rheophilous ones. The first group is constituted by species living in small and strongly eutrophic waters. Such species are usually common and numerous in different kinds of water bodies. Argillotrophic species found in waters with increased mineralization show a 
higher preference of habitats with gravel or clay bottoms. Rheophilous species are characteristic of less eutrophic waters and tyrphophilous species of polyhumic waters. Water beetles can be extremely sensitive to environmental factors and readily respond to changes (Foster et al. 2009; Foster and Eyre 1992; Menetrey et al. 2005; Giora et al. 2010a, b). Some of the most essential habitat elements which affect the abundance, species richness and nature of a community are the type of substrate, size of the pond, plant successional stage and the diversity of macrophytes, which create a habitat occupied by aquatic beetles (Pakulnicka 2008; Pakulnicka and Nowakowski 2012) and other taxonomic groups (Buczyński and Pakulnicka 2000; Weigand and Stadler 2000; Lewin 2006; Lewin and Smoliński 2006; Jurkiewicz-Karnkowska 2011).

The purpose of this study is to determine the species richness (expressed as the number of species), biodiversity (the $H^{\prime}$ index) and synecological structure of assemblages of water beetles living in clay pits and gravel pits. It also aims to identify the effect of physical and chemical parameters of water on the character of communities of beetles. The habitats were analyzed in the context of nature conservation. They are a relatively uncommon and rarely studied subject, yet they are attractive environments for numerous species of beetles, including rare, threatened and thermophilous ones as well as other taxonomic groups.

\section{Materials and methods}

The analyzed area and research methods

Field studies on water beetles dwelling in ponds formed in excavation pits were conducted at regular monthly intervals from May 1997 to October 1999. Forty-four ponds situated in the Masurian Lake District were investigated. The ponds were located in the following

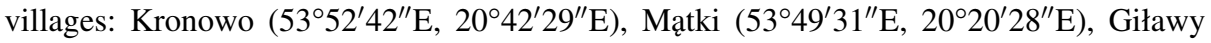
$\left(53^{\circ} 43^{\prime} 37^{\prime \prime} \mathrm{N}, 20^{\circ} 48^{\prime} 03^{\prime \prime} \mathrm{E}\right)$, Parleza Mała $\left(53^{\circ} 50^{\prime} 24^{\prime \prime} \mathrm{N}, 21^{\circ} 01^{\prime} 02^{\prime \prime} \mathrm{E}\right)$, Parleza Wielka $\left(53^{\circ} 51^{\prime} 03^{\prime \prime} \mathrm{N}-53^{\circ} 51^{\prime} 12^{\prime \prime} \mathrm{N}, \quad 21^{\circ} 00^{\prime} 26^{\prime \prime} \mathrm{E}-21^{\circ} 00^{\prime} 37^{\prime \prime} \mathrm{E}\right)$ and Najdymowo $\left(53^{\circ} 52^{\prime} 18^{\prime \prime} \mathrm{N}-\right.$ $53^{\circ} 52^{\prime} 27^{\prime \prime} \mathrm{N}, 20^{\circ} 53^{\prime} 33^{\prime \prime} \mathrm{E}-20^{\circ} 53^{\prime} 35^{\prime \prime} \mathrm{E}$ ) (Fig. 1). These ponds were a priori divided into two groups, clay and gravel, based on the pond substrate. There were differences between the ponds caused by four distinct types of environmental factors, as described by Pakulnicka (2008), i.e. type of substrate (clay, gravel), stage of formation of aquatic plants, which corresponds to different plant succession stages (young ponds without any macrophytes, older ones with poorly grown but diverse vegetation, and mature ponds, in which the zone of emergent plants is composed of compact and almost uniform patches of reeds, dominated by Phragmites australis), surface area (from $30 \mathrm{~m}^{2}$ to 1 ha), and depth (0.5 to $10 \mathrm{~m}$ ). Samples of fauna were collected from different depths: ranging from the ecotone layer at about $5-10 \mathrm{~cm}$ deep, to $60 \mathrm{~cm}$ deep, which is where water beetles mostly occurred (Table 1). For the identification of the physical and chemical parameters which differentiated the analyzed ponds in terms of the substrate and succession stage, 12 representative man-made ponds were selected, from which water samples for physical and chemical assays were collected in the spring, summer and autumn.

Throughout the whole research, 561 samples of fauna were collected, in which 8,154 aquatic beetles representing 125 species were identified (Pakulnicka 2008). Samples were collected with the standard semi-quantitative method into a D-net fitted on a triangular hoop, a tool that ensured good contact with the surface of water as well as the bottom of the pond, where startled imagines tend to hide. A single sample consisted of 20 scooping movements stretching to about $1 \mathrm{~m}$ in length. From each sample, all captured individuals 

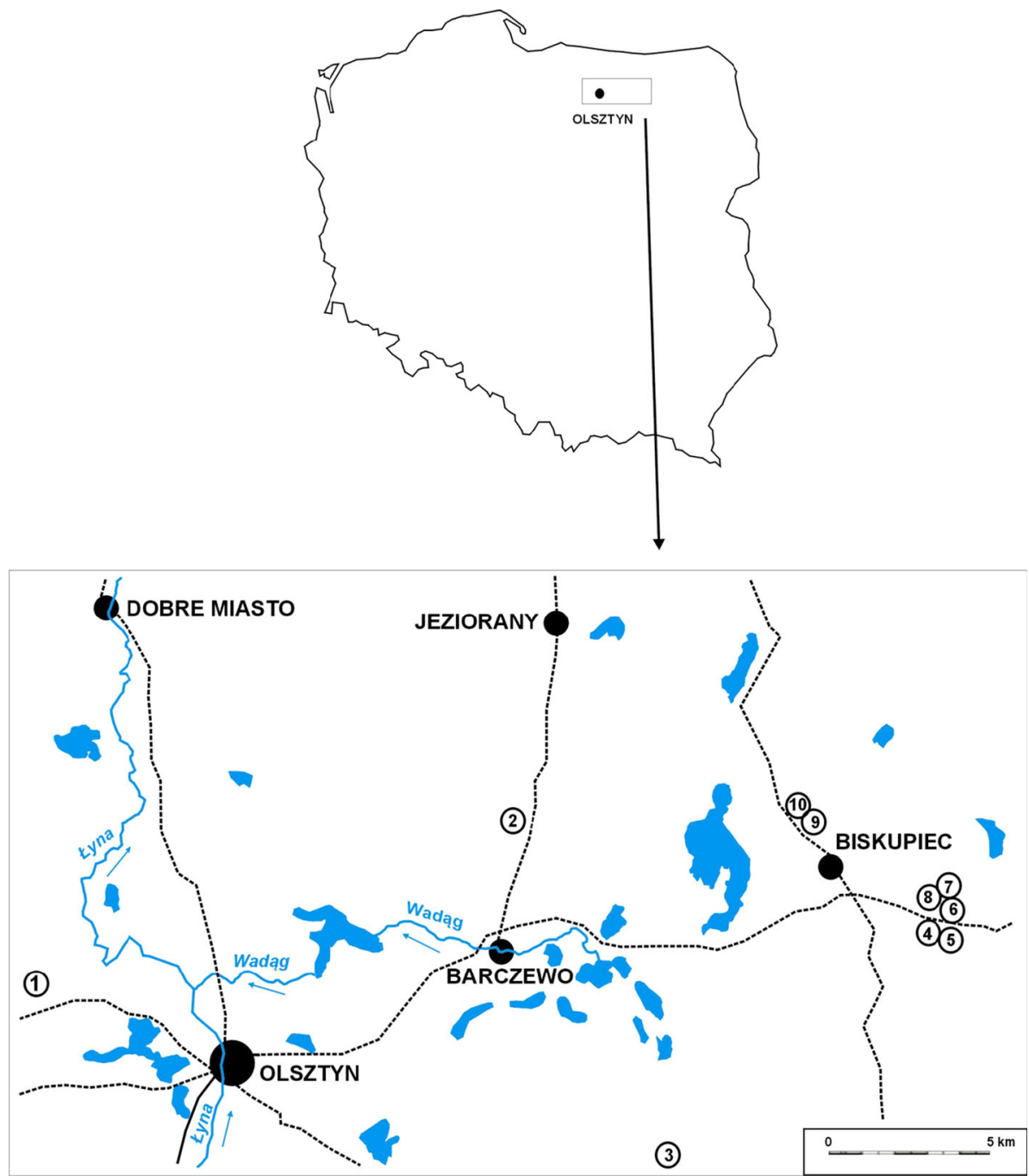

Fig. 1 Location of the study area: 1 Kronowo, 2 Mątki, 3 Giławy, 4, 5 Parleza Mała, 6, 7, 8 Parleza Wielka, 9, 10 Najdymowo

were removed, which assured the preservation of appropriate quantitative ratios. In order to assess the effect of physical and chemical parameters of pond water on the number of beetles, species diversity and synecological structure of beetle communities, the previously gathered material (Pakulnicka 2008) was reduced to samples originating from the ponds for which analyses of physical and chemical water parameters were made. In total, 166 fauna samples were considered (134 from clay and 32 from gravel pits).

The chemical composition of water was analyzed according to the procedures and standard methods described by Hermanowicz et al. (1999). The oxygen content was determined by the YSI 58 electrode). Water $\mathrm{pH}$ was measured using the Sentron 2001 electrode. Free carbon dioxide $\left(\mathrm{CO}_{2}\right)$ was measured by titration with sodium carbonate 
Table 1 General characteristics of two groups of water ponds differing in kind of substrate

\begin{tabular}{lll}
\hline Characteristic & Clay pits & Gravel pits \\
\hline Substrate & Clay & Sand \\
Area & $30 \mathrm{~m}^{2}-1$ ha & $100 \mathrm{~m}^{2}-0.5$ ha \\
Depth & $1-10 \mathrm{~m}$ & $0.5-3 \mathrm{~m}$ \\
Sampling depth & $1-60 \mathrm{~cm}$ & $1-60 \mathrm{~cm}$ \\
Stage of succession & Young-older-old & Young-older-old \\
Macrophyte cover & Complete absence-sparse and diverse & Compact stand of Phragmites australis \\
Number of samples & 134 & 32 \\
Number of species $(S)$ & $18.05 \pm 11.42$ & $5.55 \pm 4.13$ \\
Numerous & $100.39 \pm 90.43$ & $18.55 \pm 18.31$ \\
$H^{\prime}$ index & $1.74 \pm 1.14$ & $0.52 \pm 1.92$ \\
\hline
\end{tabular}

using phenolphthalein as an indicator. Ammonia nitrogen $\left(\mathrm{NH}_{4}-\mathrm{N}\right)$ was determined colorimetrically (Shimadzu UV-1601 spectrophotometer) by direct Nesslerization. Total nitrogen $\left(\mathrm{N}_{\text {tot }}\right)$ was determined colorimetrically (EPOLL-20 ECO), as nitrate ions, after microwave digestion. Concentration of phosphates $\left(\mathrm{PO}_{4}-\mathrm{P}\right)$ was assayed by colorimetrically with the molybdate method. After the digestion of samples in sulfuric acid with added ammonium persulfate, total phosphorus was determined colorimetrically with the molybdate method. The content of organic phosphorus $\left(\mathrm{P}_{\text {org }}\right)$ was calculated as the difference between the concentrations of total phosphorus and phosphates: $\mathrm{P}_{\text {org }}=\mathrm{P}_{\text {tot }}-$ $\mathrm{PO}_{4}-\mathrm{P}$. The biological oxygen demand $\left(\mathrm{BOD}_{5}\right)$ was determined using the YSI 58 electrode. Carbonates and hydrogen carbonates were assessed by titration using phenolphthalein and methyl orange as indicators. Nitrates $\left(\mathrm{NO}_{3}{ }^{-} \mathrm{N}\right)$, chlorides $\left(\mathrm{Cl}^{-}\right)$and sulfates $\left(\mathrm{SO}_{4}{ }^{2-}\right)$ were analyzed by ionic chromatography on a liquid chromatographer type METHROM 690. The specific conductivity was determined with a WTW DIGI 610 conductometer.

For the identification of statistically significant differences in the physical and chemical parameters of water between the two different groups of ponds, a $t$ test for independent variables was performed for parameters which showed normal distribution (Shapiro-Wilk test at $p<0.05$ ) and homogeneity of variance (Levene test at $p<0.05$ ), that is for $\mathrm{P}_{\text {org }}$, $\mathrm{SO}_{4}{ }^{2-}, \mathrm{HCO}_{3}{ }^{-}, \mathrm{CO}_{3}{ }^{2-}, \mathrm{T}\left({ }^{\circ} \mathrm{C}\right), \% \mathrm{O}_{2}, \mathrm{BOD}_{5}$, conductivity and $\mathrm{pH}$. The other parameters (Table 2) were submitted to a non-parametric Mann-Whitney test at $p<0.05$. In order to determine statistically significant differences in the physical and chemical parameters of water between two groups of ponds-clay pits and gravel pits, sub-divided into three groups according to prevalence of macrophytes (young ponds with no macrophytes, ponds with poorly grown vegetation and ponds overgrown with compact patches of reed), thus representing different succession stages - a non-parametric ANOVA test (Kruskal-Wallis test) was applied. Using Spearman's non-parametric correlation of ranks, at $p<0.05$, an attempt was made to identify the relationship between the parameters of water versus the type of substrate and the succession stage of plants in the analyzed ponds.

In order to correct the error due to an uneven number of faunistic samples collected from the two groups of ponds with different substrates, counts of particular species in the analyzed water bodies were replaced with values representing the mean abundance of a species in a sample, which were later included in the statistical analyses. Species diversity was determined by the number of species $(S)$ and the Shannon-Weaver index $\left(H^{\prime}\right)$ (Krebs 
Table 2 Mean values $( \pm \mathrm{SD})$ of chemical variables of two groups of water bodies differing in type of substrate
In bold statistically significant differences $(p<0.05)$ between mean values for the groups

\begin{tabular}{lcc}
\hline Parameter & \multicolumn{1}{c}{ Clay pits } & \multicolumn{1}{c}{ Gravel pits } \\
\hline $\mathrm{T}\left({ }^{\circ} \mathrm{C}\right)$ & $13.17 \pm 2.97$ & $13.57 \pm 2.37$ \\
$\mathrm{O}_{2}\left(\mathrm{mg} / \mathrm{dm}^{3}\right)$ & $10.39 \pm 1.6$ & $10.62 \pm 2.06$ \\
$\% \mathrm{O}_{2}$ & $97.67 \pm 10.0$ & $101.23 \pm 19.97$ \\
$\mathrm{BOD}_{5}\left(\mathrm{mg} \mathrm{O} / \mathrm{dm}^{3}\right)$ & $\mathbf{2 . 9} \pm \mathbf{0 . 9 7}$ & $\mathbf{4 . 4 7} \pm \mathbf{1 . 8 2}$ \\
$\mathrm{Conductivity}(\mu \mathrm{S} / \mathrm{cm})$ & $\mathbf{4 3 6 . 1 1} \pm \mathbf{9 9 . 9}$ & $\mathbf{2 0 3 . 1 1} \pm \mathbf{6 1 . 1 3}$ \\
$\mathrm{pH}$ & $7.96 \pm 0.24$ & $8.1 \pm 0.44$ \\
$\mathrm{CO}_{3}{ }^{2-}\left(\mathrm{mg} / \mathrm{dm}^{3}\right)$ & $0.42 \pm 1.0$ & $1.17 \pm 2.34$ \\
$\mathrm{HCO}_{3}{ }^{-}\left(\mathrm{mg} / \mathrm{dm}^{3}\right)$ & $\mathbf{1 6 9 . 7 8} \pm \mathbf{1 9 . 6}$ & $\mathbf{1 1 6 . 5 3} \pm \mathbf{3 5 . 1 3}$ \\
$\mathrm{Cl}^{-}\left(\mathrm{mg} / \mathrm{dm}^{3}\right)$ & $\mathbf{6 . 5 7} \pm \mathbf{2 . 9 2}$ & $\mathbf{2 . 8 1} \pm \mathbf{2 . 0 4}$ \\
$\mathrm{SO}_{4}{ }^{2-}\left(\mathrm{mg} / \mathrm{dm}^{3}\right)$ & $\mathbf{8 9 . 8 5} \pm \mathbf{4 1 . 9 7}$ & $\mathbf{6 . 5 2} \pm \mathbf{9 . 5 9}$ \\
$\mathrm{CO}_{2}\left(\mathrm{mg} / \mathrm{dm}^{3}\right)$ & $15.45 \pm 4.76$ & $3.55 \pm 5.01$ \\
$\mathrm{NH}_{4}-\mathrm{N}\left(\mathrm{mg} / \mathrm{dm}^{3}\right)$ & $0.12 \pm 0.04$ & $0.12 \pm 0.08$ \\
$\mathrm{Tot}_{-} \mathrm{N}\left(\mathrm{mg} / \mathrm{dm}^{3}\right)$ & $0.89 \pm 0.4$ & $1.21 \pm 0.08$ \\
$\mathrm{PO}_{4}-\mathrm{P}\left(\mathrm{mg} / \mathrm{dm}^{3}\right)$ & $0.01 \pm 0.003$ & $0.02 \pm 0.01$ \\
$\mathrm{Tot}_{-} \mathrm{P}\left(\mathrm{mg} / \mathrm{dm}^{3}\right)$ & $\mathbf{0 . 0 7} \pm \mathbf{0 . 0 2}$ & $\mathbf{0 . 1 1} \pm \mathbf{0 . 0 4}$ \\
${\mathrm{P} \text { org. }\left(\mathrm{mg} / \mathrm{dm}^{3}\right)}^{\mathbf{0 . 0 6} \pm \mathbf{0 . 0 2}}$ & $\mathbf{0 . 0 9} \pm \mathbf{0 . 0 3}$ \\
\hline
\end{tabular}

1996). Next, the data employed for analyses underwent logarithmic transformation to achieve a distribution as close to the normal one as possible. In order to examine the correlations between abundance, number of species or the $H^{\prime}$ index and each parameter, Spearman's rho non-parametric correlation was applied at $p<0.05$ (Sokal and Rohlf 1995). The correlation strength was assessed on a scale commonly used in statistics, where $\mathrm{rXY}=0$ variable not correlated, $0<\mathrm{rXY}<0.1$ very weak correlation, $0.1<\mathrm{rXY}<0.3$ weak correlation, $0.3<\mathrm{rXY}<0.5$ average correlation, $0.5<\mathrm{rXY}<0.7$ high correlation, $0.7<\mathrm{rXY}<0.9$ very high correlation, $0.9<\mathrm{rXY}<1$ almost complete correlation.

All of the calculations were performed using Statistica 10 software. The principal component analysis (PCA; Joliffe 1986), was performed to assess the relationships between abundance, number of species and the Shannon-Weaver index $\left(H^{\prime}\right)$ versus the environmental parameters The PCA analysis was also employed to demonstrate which factors most significantly affected the formation of synecological assemblages. The PCA analysis was also used to demonstrate which factors most significantly affected the formation of the presence of aquatic beetles in all of the analyzed samples. Only the most numerous species, which contributed more than $1 \%$ to the total collected material, were submitted to an analysis of correlation with environmental factors.

\section{Results}

Physicochemical parameters of water in the studied ponds

Among the physical and chemical parameters of water in ponds with different types of substrate, the ones which demonstrated statistically significant differences were distinguished (Table 2). These are: water conductivity, $\mathrm{HCO}_{3}{ }^{-}(t$ test, $p<0.05), \mathrm{Cl}^{-}, \mathrm{SO}_{4}{ }^{2-}$ 
(Mann-Whitney's test, $p<0.05$ ), followed by $\mathrm{P}_{\text {tot }}$, $\mathrm{P}_{\text {org }}$ and $\mathrm{BOD}_{5}(t$ test, $p<0.05)$. The remaining parameters did not reveal any statistically significant differences between the given groups of ponds. Water conductivity, $\mathrm{SO}_{4}{ }^{2-}, \mathrm{HCO}_{3}{ }^{-}$and $\mathrm{Cl}^{-}$were significantly lower in clay pits. The other parameters were higher in ponds with a gravel bottom.

\section{Characteristics of aquatic beetles}

The analyzed material consisted of 1976 water beetles $(24.2 \%$ of the whole collected material) (Pakulnicka 2008), which represented 87 species (Online Appendix), that is $68 \%$ of the species richness determined in all the analyzed water bodies. 78 species were found in clay pits, while gravel pits were inhabited by 37 species. The mean values \pm SD species richness (number of species $\mathrm{S}$ ) found in all clay pits as well as the mean value of the Shannon-Weaver index $\left(H^{\prime}\right)$ and the average number of individuals were distinctly higher than the average values determined for gravel pits. In clay pits the values were: 18.5 $( \pm 11.4), 1.7( \pm 1.1), 100.4( \pm 90.4)$ respectively; while gravel pits scored:5.5 $( \pm 4.1), 0.5$ $( \pm 1.9), 18.5( \pm 18.3)$ respectively.

The average values of the number of beetles $(N)$, species richness $(S)$ and the ShannonWeaver index $\left(H^{\prime}\right)$ in ponds with different bottom material showed statistically significant differences $(t$ test, $p<0.05$ ). With respect to ponds which differed in plant succession stage, statistically significant differences were observed only in the mean values of species richness $(S)(H=8.79, p=0.01)$ and the Shannon-Weaver index $\left(H^{\prime}\right)(H=7.5$, $\mathrm{p}=0.02)$. Differences in the average abundance of beetles $(N)$ between successive stages of plant succession were marginally significant $(p=0.07)$ (the Kruskal-Wallis test, $p<0.05$ ). Differences in values of the mentioned indices were noticed between young ponds without aquatic vegetation and mature ponds completely overgrown with compact patches of reed.

The species which were most numerous in the collected material were: Laccobius minutus (14.2\% of all beetles), Noterus crassicornis (12.7\%), Laccophilus minutus (8.3\%), Scarodytes halensis (6.2\%), Graptodytes pictus (4.7\%), Peltodytes casus $(4.6 \%)$ and Hydroglyphus hamulatus $(4.3 \%)$. Considering the average number of representatives of a given species per sample obtained from a particular type of pond, the most numerous species in clay pits were $N$. crassicornis (on average 1.87 individual per sample), L. minutus (1.42), L. minutus (1.1) and S. halensis (0.9). These values are much higher when samples in which a given species did not occur are excluded (Online Appendix). The most numerous species in gravel pits were L. minutus (on average 2.81 individuals per sample) and L. minutus (0.59). The number of beetles $(N)$ in particular ponds was strongly correlated with the species richness $(S)$, both in clay pits $(R=0.79, p=0.0001)$, and in gravel pits filled with water $(R=0.9, p=0.0001)$. Correlations between the number of individuals $\mathrm{N}$ and values of the Shannon-Weaver index $\left(H^{\prime}\right)$ in particular types of the studied ponds proved to be non-significant (Spearman $R, p<0.05$ ).

The beetles dwelling in the analyzed ponds are characterized by high synecological diversity. Four groups of species can be distinguished (Pakulnicka 2008): eurytopic (54.1\% of all determined species), rheophilous (18.8\%), tyrphophilous $(14.1 \%)$ and argillophilous beetles (12.9\%) (Online Appendix). Counts of all the distinguished groups, except argillophiles, are significantly different between clay and gravel pits (MannWhitney test, $p<0.05$ ) and between ponds representing different succession stages (Kruskal-Wallis test, $p<0.05$ ). These three groups of beetles demonstrate a strong correlation with the type of bottom substrate (Spearman $R, p<0.05$ ). 
Analysis of the relationships between Coleoptera and environmental factors

Based on the conducted PCA analysis and correlation matrix between selected biocoenotic indices and observed environmental parameters, certain correlations were observed that can be described as significant to the formation of beetle fauna in clay and gravel pits. Undoubtedly, water temperature is a factor which strongly affects the counts of beetles inhabiting clay pits, their species richness $(S)$ and the value of the Shannon-Weaver index $\left(H^{\prime}\right)(r=-0.46, p<0.05)$; these three characteristics are affected by $\mathrm{CO}_{3}{ }^{2-}, \mathrm{CO}_{2}, \mathrm{PO}_{4}-\mathrm{P}$ or $\mathrm{Cl}^{-}$(Fig. 2a). Apart from water temperature, $\mathrm{NH}_{4}-\mathrm{N}$, total $\mathrm{N}, \mathrm{BOD}_{5}$ and $\mathrm{HCO}_{3}{ }^{-}$are significant factors in the waters of gravel pits (Fig. 2b).

The physical and chemical parameters of water also have a significant impact on the formation of synecological assemblages. A strong relation was determined in clay pits between eurytopic, rheophilous and argillophilous beetles versus conductivity, $\mathrm{SO}_{4}{ }^{2-}$ and $\mathrm{Cl}^{-}$, and between rheophilous beetles versus $\mathrm{NH}_{4}-\mathrm{N}, \mathrm{P}_{\text {org }}$ and $\mathrm{BOD}_{5}$ (Fig. 3a). In gravel pits tyrphophilous, eurytopic and rheophilous species show the strongest correlation with temperature and $\mathrm{pH}$, while argillophilous beetles are most correlated with $\mathrm{BOD}_{5}$, organic $\mathrm{P}$ and $\mathrm{HCO}_{3}^{-}$(Fig. 3b).

Based on the PCA analysis it might be worth to discuss the impact of factors that seem to be distinguishing clusters of points representing certain species of beetles. The obtained statistical results are further supported by synecological descriptions of certain groups of species representing similar or approximate habitat preferences-which is expressed in these species' common coexistence.

In clay pits the presence of $S$. halensis is correlated with the value of conductivity as well as $\mathrm{SO}_{4}{ }^{2-}$ and $\mathrm{Cl}^{-}$, while Hygrotus versicolor, Bidessus hamulatus, Haliplus lineolatus, Haliplus fulvus, Haliplus fluviatilis and Haliplus flavicollis show a correlation with $\mathrm{Cl}^{-}$and $\mathrm{P}_{\text {org }}, \mathrm{SO}_{4}{ }^{2-}$, conductivity and with $\mathrm{BOD}_{5}$ (Fig. 4a). Other species which are evidently represented in the achieved diagram are Helophorus minutus, L. minutus, $P$. casus, Hygrotus inaequalis and Haliplus ruficollis, for which the correlation was with $\mathrm{NH}_{4}-$ $\mathrm{N}$ and organic $\mathrm{P}$, as well as G. pictus, H. lineolatus and H. minutus-correlated with total $\mathrm{P}$, organic $\mathrm{P}$ and $\mathrm{CO}_{3}{ }^{2-}$. In ponds formed in gravel pits, Anacaena lutescens, $H$. minutus and L. minutus show a distinct correlation with $\mathrm{P}_{\text {org }}, \mathrm{CO}_{3}{ }^{2-}$, total $\mathrm{P}, \mathrm{pH}$ and $\mathrm{BOD}_{5}$. G. pictus, Noterus crassicornis, L. minutus are correlated with $\mathrm{HCO}_{3}{ }^{-}, \mathrm{CO}_{2}$ and conductivity while Helochares griseus and Limnebius truncatulus are correlated with NH4-N, organic P and total N (Fig. 4b).

\section{Discussion}

Rare, threatened and valuable species in assemblages of aquatic beetles

According to Bogdanowicz et al. (2004), there are about 350 species of aquatic beetles living in different types of water bodies of Poland. The list of species identified in the analyzed abandoned excavation pits comprises 85 species, which corresponds to $24.3 \%$ of the species richness of beetles in Poland. Considering all the water bodies examined throughout the whole research period (Pakulnicka 2004, 2008), this percentage increases to $35.7 \%$ and is only slightly smaller than the species richness thus far determined in natural water environments, for example in the lakes and ponds of Olsztyn, a town situated in the heart of the region (Pakulnicka and Biesiadka 2011). In Poland, five species are under full legal protection (Regulation 2011), two are listed in the Polish Red Book of Animals 
Fig. 2 The principal component analysis (PCA) ordination plot of abundance, richness and diversity of water beetles colonizing clay pits (a) and gravel pits (b) in relation to the environmental variables in samples along the first and second PCA axis
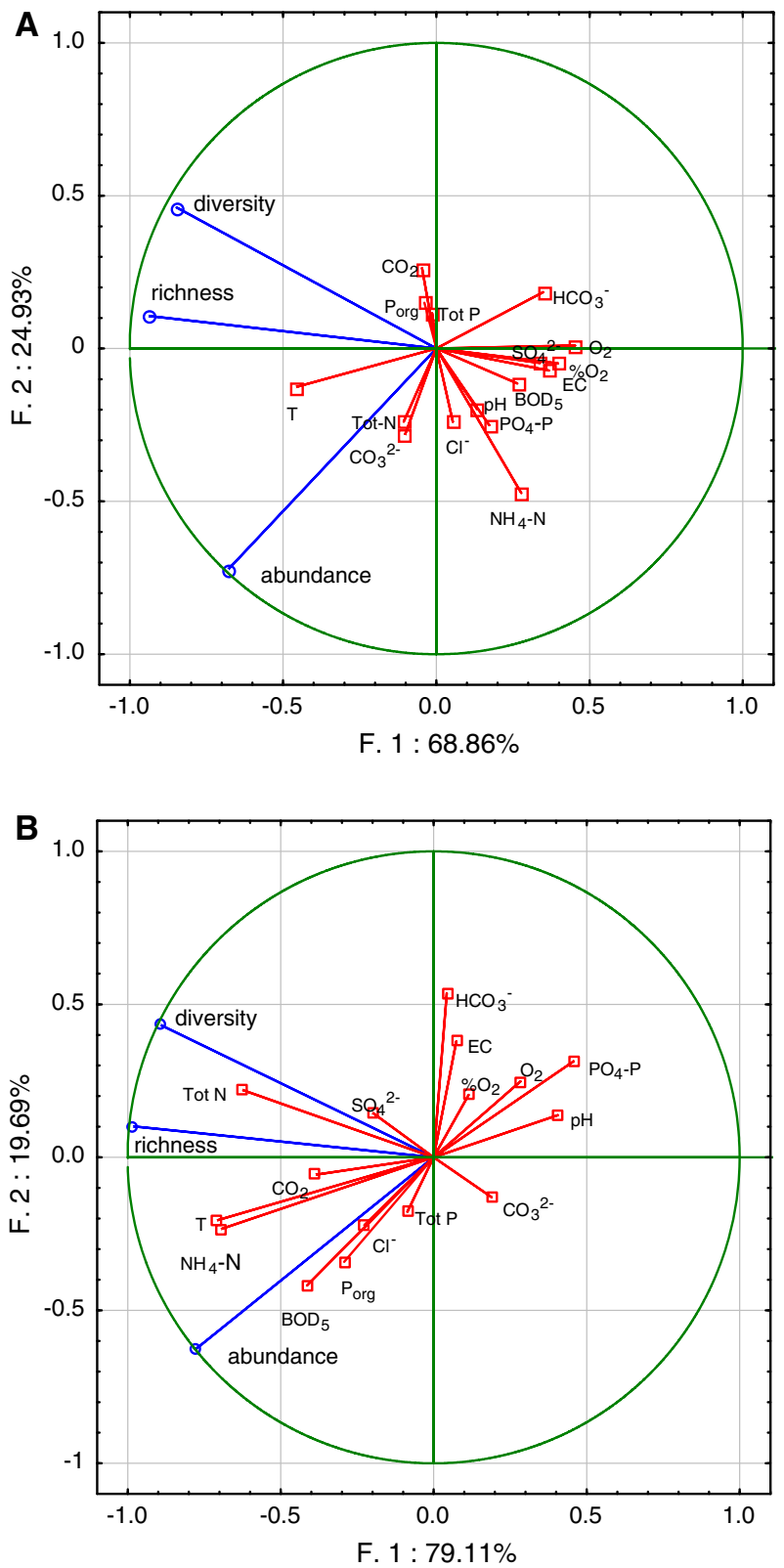

(Glowacinski and Nowacki 2004), 48 feature on the Polish Red List of disappearing or threatened animals (Pawlowski et al. 2002). During our study, only one species given total legal protection in Poland (Hydrophilus aterrimus) and three species from the Polish Red List, assigned with different statuses of endangered species (Haliplus fulvicollis VU, $H$. 

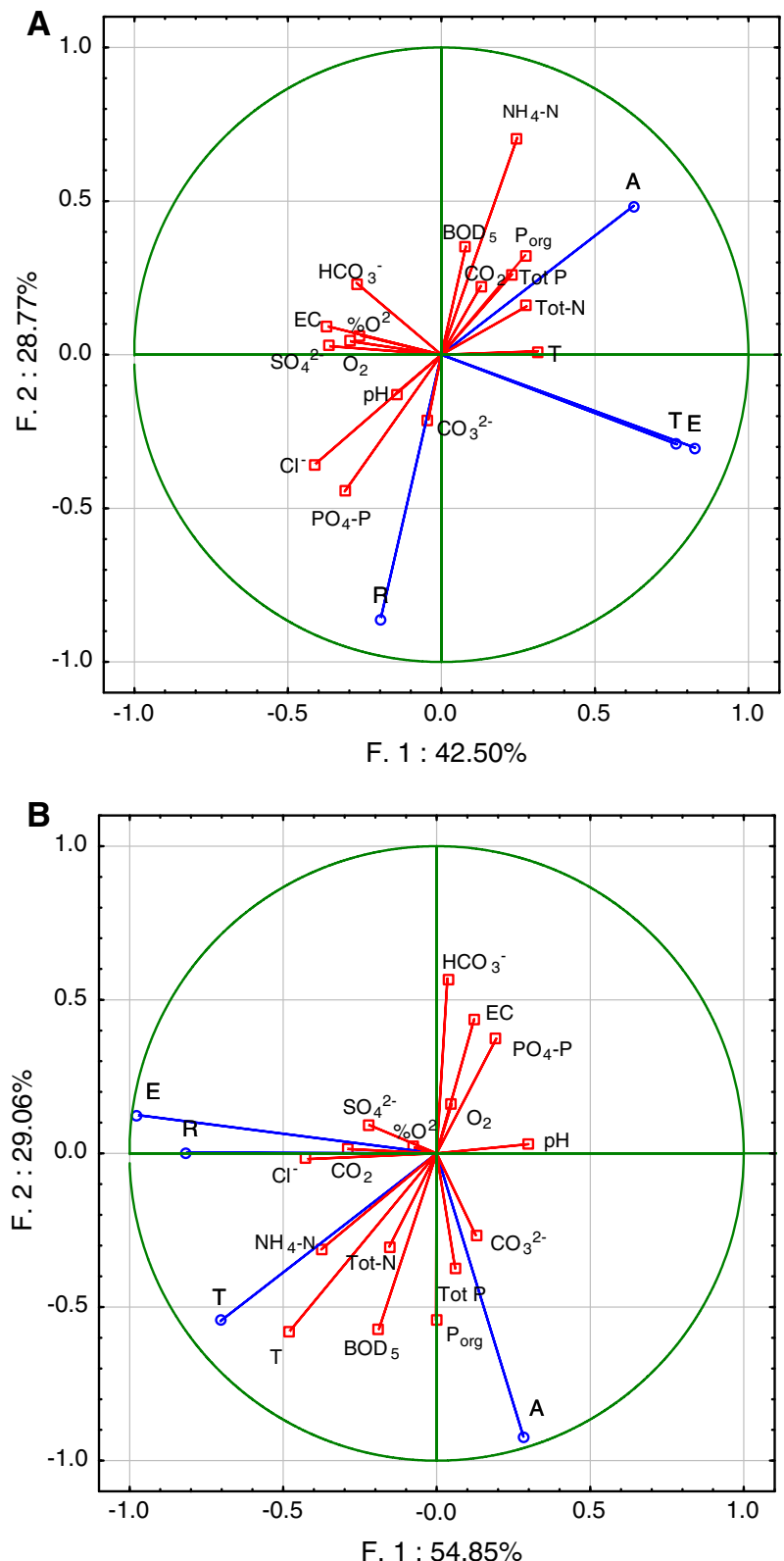

Fig. 3 The principal component analysis (PCA) ordination plot of occurrence of synecological group ( $E$ eurytopic species, $A$ argillophilous species, $R$ reophilous, $T$ tyrphophilous species) among water beetles colonizing clay pits (a) and gravel pits (b) in relation to the environmental variables in samples along the first and second PCA axis

aterrimus VU and Gyrinus caspius EN), were found in the studied ponds. For comparison, Pakulnicka and Biesiadka (2011) report two species under strict legal conservation and three species found on the Polish Red List. 
Fig. 4 The principal component analysis (PCA) ordination plot its of occurrence of selected species of water beetles colonizing clay pits (a) and gravel pits (b) in relation to the environmental variables in samples along the first and second PCA axis
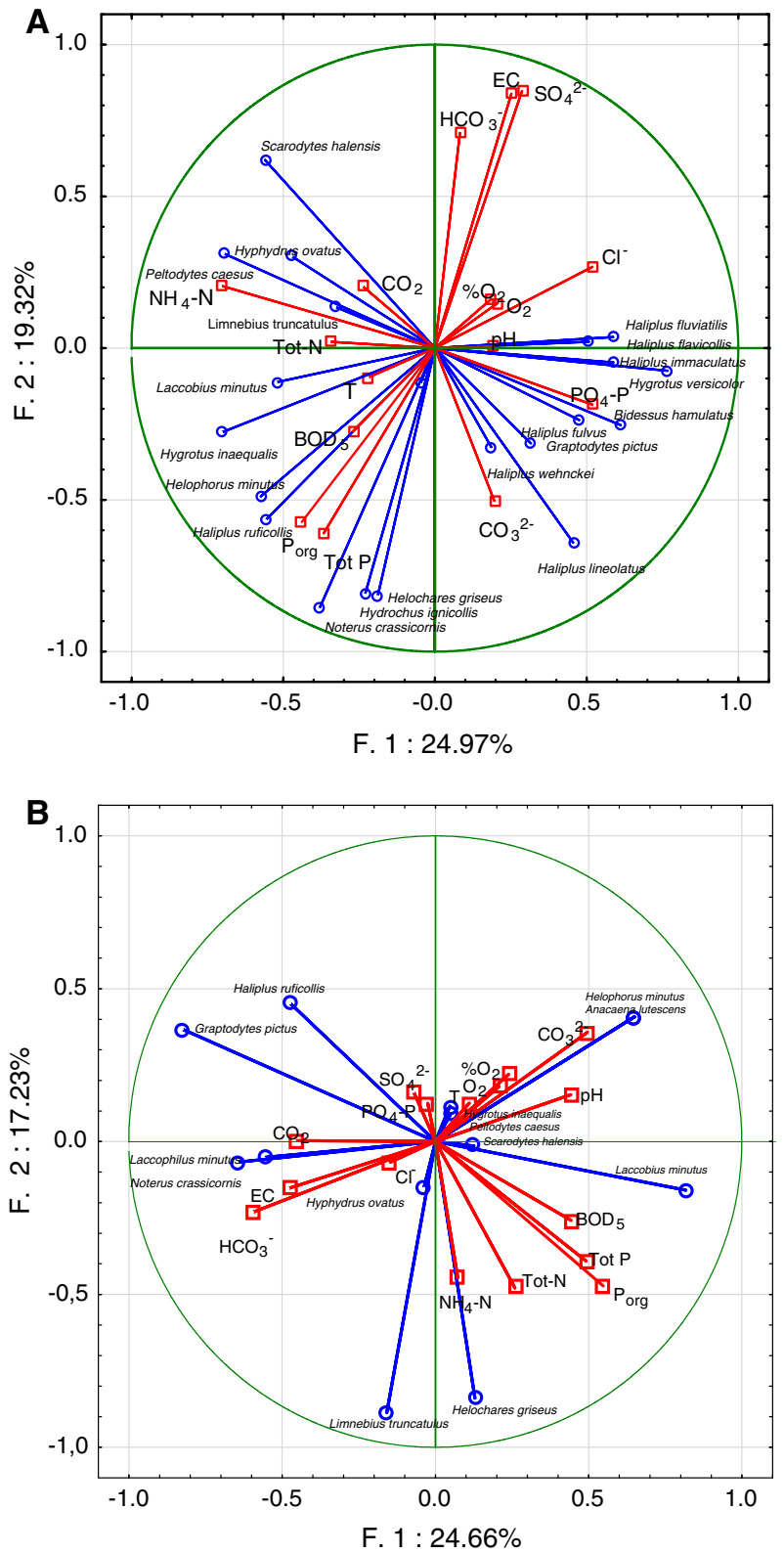

Several other valuable species of beetles were identified, rarely found in aquatic habitats throughout Poland and typically captured as single specimens. Therefore, it seems that their lasting presence in Polish wildlife is threatened. These species include: Gyrinus suffriani (listed on one of the local Red Lists in Poland; Buczyński and Przewoźny 2010), H. hamulatus, Colymbetes striatus, Helophorus grandis, Limnebius aluta and Limnebius papposus. Noteworthy is also the presence of Ochthebius hungaricus in the analyzed region. This species was determined by Biesiadka (1988) as a new one among the 
populations of beetles dwelling in Poland. Another identified species was Hydrochus ignicollis, whose easternmost distribution-according to Alonzo-Zarazaga and Jäch (2004) — is established by the data reported from North-Eastern Poland. However, there were some previous reports on its occurrence in the Masovian Lowland (Majewski 1998) and Masurian Lake District (Pakulnicka et al. 1998); recently, this has also been reported in other regions of Poland, including the Świętokrzyskie Mountains (Bidas and Przewoźny 2003), Wielkopolsko-Kujawska Lowland (Przewoźny 2004; Przewozny and Lubecki 2006), Pomorskie Lake District (Pakulnicka and Zawal 2007) and the Suwałki Landscape Park (Buczyński et al. 2010).

It is worth underlining that the examined ponds were also inhabited by many thermophilous species, rare to our country or to this part of Europe, but encountered in the south of the continent, e.g. Nebrioporus canaliculatus, Hygrotus confluens and Hydroglyphus geminus (Pakulnicka 2004, 2008).

The degradation of the natural aquatic environment observed across Europe, due to the eutrophication or depression of groundwater levels, has rendered many species extinct or endangered. This tendency appears to be growing distinctly stronger in the geographic gradient, producing the most profound effects in the western parts of Europe. Many species have already been added to Red Lists drawn up in various European countries, e.g. in Ireland (Bilton et al. 1992; Foster et al. 2009), the United Kingdom (Foster 2010), Norway (Kålås et al. 2010), the Czech Republic (Farkač et al. 2005) or Germany (Binot et al. 1998). According to Foster (2010), Gyrinus natator is an extinct species in Britain (ExR), but it was identified in the ponds analyzed herein (Pakulnicka 2008). Many species which in Ireland or in the UK (Foster et al. 2009; Foster 2010) have been assigned the status of threatened ones, i.e. EN, VU or NT, were collected in the analyzed ponds in high or even very high numbers. These are, for example, Hygrotus decoratus, H. versicolor, Laccophilus hyalinus, Helophorus granularis, Hydrochara caraboides, H. ignicollis and Hydrochus crenatus. The inclusion of ponds created in excavation pits into the hydrographic network is therefore of great importance not just in Poland but in the whole of Europe. The determined high species diversity as well as the presence of rare species, seldom found in aquatic habitats, proves that such ponds play an extremely important role in the ecological landscape (Buczyński 1999; Buczyński and Pakulnicka 2000; Weigand and Stadler 2000; Lewin 2006; Lewin and Smolinski 2006; Pakulnicka 2008; Jurkiewicz-Karnkowska 2011). On the one hand, they are substitute habitats, where native fauna can survive after their presence in natural habitats has become impossible. On the other hand, man-made ponds accept alien species, which expand beyond the borders of their natural occurrence, a development that enhances local diversity. Anthropogenic ponds are also a sort of refuge and donor of species to habitats which-owing to nature conservation and preservationnow have a chance of renaturalization. Ponds formed in former excavation pits should be perceived as ecological channels, which-for the sake of sustaining their functionsdeserve a special nature protection program, as suggested by other researchers, e.g. Lenda et al. (2012).

Dependence of communities of aquatic beetles on the physical and chemical parameters of water

The analyzed man-made ponds are characterized by a very high concentration of water dissolved oxygen, high average $\%$ of oxygen saturation, high alkalinity of water and a relatively low concentration of different forms of $\mathrm{N}$ and $\mathrm{P}$. The above listed water parameters did not show any statistically significant differences between the two types of 
studied water bodies with different substrates. They were, however, very close to values reported for Lobelian lakes with poor trophy (Kordylas 1990). Thus, both the clay and gravel pits contained very clean water, corresponding to water purity class I. This certainly had an effect on the number of beetles inhabiting these ponds, their species richness and species composition. The good ecological condition of the water in the analyzed ponds is manifested by the synecological structure of beetles, in which-next to the basic component formed by eurytopic beetles-another important group was composed of rheophiles, which prefer clean and well-oxygenated waters, e.g. H. lineolatus, $H$. flavicollis, $H$. fluviatilis, H. fulvus, H. versicolor and H. hamulatus, Laccopilus hyalinus or Ilybius fenestratus.

Detailed analyses of the beetle fauna found in the sites representing two types of water bodies, with two different types of substrate, imply that the type of bottom has a significant effect on the presence and number of aquatic insects (Ward 1992). Among the analyzed water parameters only a few physical and chemical characteristics differentiate the two types of habitats and can definitely affect the character of local communities of beetles. The highest statistically significant differences between the two types of anthropogenic ponds were attributed to electrolytic conductivity, which is an approximate indicator of the amount of dissolved minerals. The EC was much higher in clay than in gravel pits; this difference was supported by higher anion concentration $\left(\mathrm{HCO}_{3}{ }^{-}, \mathrm{SO}_{4}{ }^{2-}\right.$ and $\left.\mathrm{Cl}^{-}\right)$in agreement with other clay pits (Corbet et al. 1980; Jenkin 1982; Lewin and Smolinski 2006).

The electrolytic conductivity and content of minerals were the two factors that distinctly differentiated the waters of the two types of studied pits. These factors may be of great significance to locally occurring beetle fauna. Correlations between the density of various organisms versus water conductivity and concentration of ions have also been implied by Savage and Gazey (1987), as well as Jurkiewicz-Karnkowska (2011). Nonetheless, it seems that differences in the degree of macrophyte prevalence still have a greater impact on the nature of aquatic beetle clusters in the studied ponds-which is expressed in the mean values of species richness (number of species- $N$ ), mean values of the ShannonWeaver index $\left(H^{\prime}\right)$ and mean number $(N)$ of beetles. The importance of succession stages in the formation of beetle fauna in artificial water bodies is noted by, among others, Barness (1983) and Pakulnicka (2008). With all certainty, the development stage of macrophytes in the studied ponds is definitely a factor related to physical and chemical water parameters.

The PCA results show that both the abundance and species richness or biodiversity of the beetles in the examined clay pits are correlated with water temperature, but also, with $\mathrm{NH}_{4}-\mathrm{N}$, total $\mathrm{N}$ and $\mathrm{BOD}_{5}$. Values of these parameters typically change as a pond matures, which is associated with the degree of development and differentiation of emergent vegetation, providing habitats to various species of beetles, and with the rate of primary production and decomposition of organic matter. The influence of these factors proved to be more significant than the expected effect of conductivity or concentration of ions. Similar conclusions have been drawn by Lewin and Smoliński (2006), who found statistically significant correlation between the number of species of mollusks and water alkalinity but not with its conductivity.

With respect to the influence of the analyzed physical and chemical parameters of pond water on the presence of specific beetle species, noteworthy is correlation of the thermophilous species $S$. halensis with conductivity, concentrations of ions $\mathrm{HCO}_{3}{ }^{-}, \mathrm{SO}_{4}{ }^{2-}$ and temperature. Together with several other species, such as Haliplus confinis, Haliplus obliquus, $N$. canaliculatus or $H$. geminus, the beetle $S$. halensis makes up an assemblage of 
argillophilous beetles preferring waters with poor vegetation and a higher content of minerals, usually shallow ones, which warm up very quickly. This explains why argillophiles comprise species typical of Mediterranean countries (e.g. N. canaliculatus), whichby inhabiting man-made ponds-expand the borders of their distribution north- and eastwards. The presence of thermophilous species in anthropogenic ponds has also been observed in studies on other taxonomic groups, for example dragonflies (Donath 1980; Ohnesorge 1988; Buczyński 1999; Buczyński and Pakulnicka 2000).

Another distinct group of beetles combined species such as $H$. lineolatus, $H$. flavicollis, $H$. fluviatilis, $H$. fulvus, $H$. versicolor and $H$. hamulatus. These beetles are correlated with water conductivity and concentration of $\mathrm{SO}_{4}^{2}$ ions, as well as water saturation and dissolved oxygen. These species prefer well-oxygenated waters and are frequent in clean lakes, in habitats with sandy substrate, overgrown with scattered Phragmites australis, or in quiet sites located in slowly flowing rivers. Other species demonstrating a strong relationship with $\mathrm{NH}_{4}-\mathrm{N}$, organic $\mathrm{P}$, total $\mathrm{P}$ and $\mathrm{CO}_{3}{ }^{2-}$ create a community of eurytopic species, primarily associated with small eutrophic water bodies, abundantly overgrown with aquatic plants.

\section{Summary}

Anthropogenic ponds located in the Masurian Lake District, owing to their environmental characteristics, including the type of substrate, development of macrophytes, age of the pond as well as the physical and chemical parameters of the water it holds, are inhabited by a rich and diverse fauna of beetles. The physical and chemical parameters of water in the analyzed ponds correspond to the ones assigned to oligotrophic lakes in very good ecological condition. This is the reason why they have been colonized by several species whose natural habitats are disappearing, especially the ones which have been ascribed different statuses of threatened species in Europe, including H. aterrimus (VU), in Poland under total protection, H. fulvicollis (VU) and G. caspius (EN). At the same time, such ponds create suitable conditions for many rare species of the Polish fauna, which helps to sustain biodiversity, both locally and on a scale surpassing a single region. Thus, anthropogenic ponds are a valuable component of the ecological landscape and deserve to be subjected to a special nature conservation program.

Acknowledgments The authors would like to thank Prof. Eugeniusz Biesiadka for his suggestions concerning the research materials as well as his valuable comments during this study.

Open Access This article is distributed under the terms of the Creative Commons Attribution License which permits any use, distribution, and reproduction in any medium, provided the original author(s) and the source are credited.

\section{References}

Alonzo-Zarazaga A, Jäch M (2004) Ochthebius (Asiobates) flavipes Dalla Torre, 1877. [In:] Fauna Europaea ver. 1.1. Internet: http://www.faunaeur.org

Barnes LE (1983) The colonization of ball-clay by macroinvertebrates and macrophytes. Freshw Biol 13:291-297

Bidas M, Przewoźny M (2003) Contributions to the knowledge of Hydrophiloidea (Coleoptera: Hydrophiloidea) of the Świętokrzyskie Mountains. Wiad Entomol 22(1):5-12

Biesiadka E (1988) Ochthebius minervius d'Orchymont, 1940. (Coleoptera, Hydraenidae), the water beetle species new to Polish fauna. Prz Zool 32:213-215 
Bilton DT, Lott DA, Merritt R, Weyl RS, Eyre MD (1992) A classification and evaluation of Irish water beetle assemblages. Aquat Conserv Mar Freshw Ecosyst 2:185-208

Binot M, Bless R, Boye P, Gruttke H, Pretscher P (eds) (1998) Rote Liste gefährdeter Tiere Deutschlands. Schriftenr. Landschaftpfl Natursch 55:1-434

Bogdanowicz W, Chudzicka E, Pilipiuk I, Skibińska E (2004) Fauna Polski Charakterystyka i wykaz gatunków. Tom I. Muzeum i Instytut Zoologii PAN, Warszawa

Bosi G (2001) Abundance, diversity and seasonal succession of dytiscid and noterid beetles (Coleoptera: Adephaga) in two marshes of the Eastern Po Plain (Italy). Hydrobiologia 459:1-7

Buczyński P (1999) Dragonflies (Odonata) of sandpits in sought-eastern Poland. Acta Hydrobiol 41(3/ 4):219-230

Buczyński P, Pakulnicka J (2000) Odonate larvae of gravel and clay pits in the Masurian Lake District (NE Poland), with notes of extremely localities of some Mediterranean species. Notul Odonatol 5:69-70

Buczyński P, Przewoźny M (2010) Aquatic beetles (Coleoptera) of carbonate habitats in the vicinity of Chełm (eastern Poland). Ann Univ M Curie-Skłodowska (c) 65:77-105

Buczyński P, Przewoźny M, Karasek T, Kowalak E (2010) Rare, endangered and protected aquatic beetles (Coleoptera: Dytiscidae, Hydrochidae, Spercheidae, Hydrophilidae) recorded in the vicinity of Suwałki. Wiad Entomol 29(3):207-208

Carl M (1997) Inoperative gravel mine as reservoir of species for Fürtenfeldbruck (Oberbayern) area. 1. List of water insecta. NachrBl Bayer Ent 46:81-89 (in German)

Catchpole C, Tydeman Ch (1975) Gravel pits as new wetland habitats for the conservation of breeding bird communities. Biol Conserv 8:47-59

Collinson NH, Boggs J, Corfield A, Hodson MJ, Walker D, Whitfield M, Williams PJ (1995) Temporary and permanent ponds: an assessment of the effects of drying out on the conservation value of aquatic macroinvertebrate communities. Biol Conserv 74:125-133

Corbet S, Perrin R, Hartley D, Lancashire P, Mace H, McClay A, Morton J, Parfitt R, Tomiak H, Wheatley K, Willmer R, Willows R (1980) Diel changes in plankton and water chemistry in Wicken Brickpit. Hydrobiologia 74:249-271

Donath H (1980) Eine bemerkenswerte Libellenfauna an einem Kiesgrubenweiher in der Niederlausitz (Odon.). Entom Berichte 24:65-67

Eyre MD, Foster GN, Foster AP (1992) Factors affecting the distribution of water beetle species assemblages in drains of eastern England. J Appl Entomol 109:217-225. doi:10.1111/j.1439-0418.1990. tb00043.x

Farkač J, Král D, Škorpík M (eds) (2005) Červený seznam ohrožených druhů České republiky. Bezobratlí. List of threatened species in the Czech Republic. Invertebrates. Agentura ochrany přírody a krajiny ČR, Praha, p 760

Foster GN (2010) A review of the scarce and threatened Coleoptera of Great Britain Part (3): Water beetles of Great Britain. Species Status 1. Joint Nature Conservation Committee, Peterborough

Foster GN, Eyre MD (1992) Classification Ranking of Water Beetle Communities. UK Nature Conservation: 1. Joint Nature Conservation Committee, Peterborough, UK

Foster GN, Nelson BH., Connor Á (2009) Ireland Red List No. 1-Water beetles. National Parks and Wildlife Service, Department of Environment, Heritage and Local Government, Dublin, Ireland

Geißler-Strobel S, Bugner J, Feldmann R, Günther K, Gras J, Herbst F, Seluga K (1998) Bergbaufolgelandschaften in Ostdeutschland-durch Sanierung bedrohte Sekundärlebensraume. Nat Schutz Landsch Plan 30:106-112

Gioria M, Bacaro G, Feehan J (2010a) Identifying the drivers of pond biodiversity: the agony of model selection. Commun Ecol 11:179-186. doi:10.1556/ComEc.11.2010.2.6

Gioria M, Schaffers A, Bacaro G, Feehan J (2010b) The conservation value of farmland ponds: predicting water beetle assemblages using vascular plants as a surrogate group. Biol Conserv 143:1125-1133. doi:10.1016/j.biocon.2010.02.007

Głowaciński Z, Nowacki J (eds) (2004) Polish Red Data Book. Invertebrates. Instytut Ochrony Przyrody PAN. Akademia Rolnicza im. A. Cieszkowskiego, Kraków-Poznań, p 447

Hermanowicz W, Dojlido J, Dożańska W, Koziorowski B, Zerbe J (1999) Physico-chemical investigation of water and sludge. Arkady, Warszawa, p 627. (in Polish)

Hudoklin A, Sovinc A (1997) Novo življenje opuščenih glinokopov. Proteus 3:104-110

Jenkin P (1982) Temperature, hydrochemistry and plancton in Wicken Brickipits, 1930-1931. Hydrobiologia 97:37-61

Joliffe T (1986) Principal components analysis. Springer, New York

Jurkiewicz-Karnkowska E (2011) Effect of habitat conditions on the diversity and abundance of molluscs in floodplain water bodies of different permanence of flooding. Pol J Ecol 59:165-178 
Kålås JA, Viken $\AA$, Henriksen S, Skjelseth S (eds) (2010) The 2010 norwegian red list for species. Norwegian Biodiversity Information Centre, Norway

Kognitzki S (1988) Untersuchungen zur Libellenfauna von neugeschaffen Sekudärgenwässern in Nürnberg und Umgebung. Schr reihe Bayer Landesamt Umweltschutz 79:137-141

Kordylas A (1990) Chrząszcze wodne (Coleoptera) lobeliowego jeziora Krzemno. Fragm faun 33:71-81

Kowalik W, Buczyński P (2003) Beetles (Coleoptera) of saline waters from the "Bogdanka" stone coal mine (South-eastern Poland). Acta Agroph 1:115-121

Krebs ChJ (1996) Ecology. The experimental analysis of distribution and abundance, Harper Collins, New York

Lenda M, Skórka P, Moron D, Rosin ZM, Tryjanowski P (2012) The importance of the gravel excavation industry for the conservation of grassland butterflies. Biol Conserv 148:180-190. doi:10.1016/j.biocon. 2012.01.014

Lewin I (2006) The gastropod communities in the lowland rivers of agricultural areas - their biodiversity and bioindicative value in the Ciechanowska Upland, Central Poland. Malacologia 49:7-23

Lewin I, Smoliński A (2006) Rare, threatened and alien species in the gastropod communities in the clay pit ponds in relation to the environmental factors (The Ciechanowska Upland, Central Poland). Biodivers Conserv 15:3617-3635. doi:10.1007/s10531-005-8347-4

Lipsey L, Malcolm S (1981) Summer zooplankton communities of selected borrow-pit ponds in Northern Illinois. Hydrobiologia 77:81-85

Majewski T (1998) New and rare Hydraenidae i Hydrochidae (Coleoptera) w Polsce. Acta entomol silesiana 5-6:21-23

Menetrey N, Sager L, Oertli B, Lachavanne JB (2005) Looking for metrics to assess the trophic state of ponds. Macroinvertebrates and amphibians. Aquat Conserv Mar Freshw Ecosyst 15:653-664

Ohnesorge D (1988) Die Libellenfauna (Odonata) der Kiesgrube Barkholz (Kreis Stormarn, SchleswigHolstein). Seevögel 9:17-25

Ott J (1995) Die Beeinträchtigung von Sand- und Kiesgruben durch intensive Angelnutzung-Auswirkungen auf die Libellenfauna und planerische Lösungsansätze. Limnol aktuell 7:155-170

Pakulnicka J (2004) The aquatic beetles in post-exploitation water bodies in Poland. Latissimus 18:22-26

Pakulnicka J (2008) The formation of water beetle fauna in anthropogenic water bodies. Oceanol Hydrobiol Stud 37:31-42. doi:10.2478/v10009-007-0037-y

Pakulnicka J, Biesiadka E (2011) Water beetles fauna of Olsztyn (Poland). In: Indykiewicz P et al. (eds) Urban fauna. Studies of animal biology, ecology and conservation in the European Cites. University of Technology and Life Sciences, Bydgoszcz, pp 305-317

Pakulnicka J, Nowakowski JJ (2012) The effect of hydrological connectivity on water beetles fauna in water bodies within the floodplain of a lowland river (Neman river, Belarus). Oceanol Hydrobiol Stud 41:7-17. doi:10.2478/s13545-012-0012-4

Pakulnicka J, Zawal A (2007) Chrząszcze wodne (Coleoptera) rezerwatu jezioro Szare i jego otuliny. Parki nar Rez Przyr 26:121-133

Pakulnicka J, Eyre M, Czachorowski S (1998) Materials to the knowledge of water and semiaquatic beetles (Coleoptera) if the vicinity of Olsztyn. Wiad Entomol 17:69-74

Pawłowski J, Kubisz D, Mazur M (2002) Coleoptera Chrząszcze. In: Głowaciński Z (ed) Red list of threatened animals in Poland. Polish Academy of Sciences, Institute of Nature Conservation, Cracow, pp 88-110

Przewoźny M (2004) New records of the Hydrophiloidea (Coleoptera: hydrophiloidea) w Polsce. Wiad Entomol 23(2):69-80

Przewoźny M, Lubecki K (2006) New localities of rare water beetles of the superfamily Hydrophiloidea (Coleoptera) and family Hydraenidae (Coleoptera: Staphylinoidea) in Poland. Wiad Entomol 25(4):213-217

Regulation of the Minister of Environment of 12 October 2011 on the protection of species of animals. Acts. Laws 237, item. In 1419

Savage AA, Gazey GM (1987) Relationships of physical and chemical conditions to species diversity and density of Gastropods in English Lakes. Biol Conserv 42:95-113

Sokal RR, Rohlf FJ (1995) Biometry: The principles and practice of statistics in biological research, 3rd edn. WH Freeman, New York

Spitzenberg G (1988) Interesting water beetles species (Coleoptera, Palpicornia) from district Magdeburg. Entomol Nachr Ber 32:207-209

Sternberg K (1997) Warum eignen sich Sekundärbiotope nur bedingt als Refugium für Libellen (Odonata). Veröff Nat schutz Landsch pfl Baden-Württ 71(72):233-243

Stöckel G (1983) Inconspicuous gravel-pits: a place where curious dragon-fly and water beetles species are found. Entomol Nachr Ber 27:215-219 
Trahms KJ (1972) Die Etwicklung von Plankton-Biocoenosen in Restgewässern des Rheinischen Braunkohlengebietes. Int Revue Ges Hydrobiol 57:695-758

Trockur B (1997) Bemerkenswerte Libellenfunde im Kiesweihergebiet bei Remerschen: wiederfund von Epitheca bimaculata und Erstnachweis von Anax parthenope fur Luxemburg (Insecta, Odonata). Bull Soc Nat Luxemb 98:105-112

Ward JW (1992) Aquatic insect ecology 1 Biology and habitat. Willey, New York

Weigand E, Stadler F (2000) Die aquatischen Mollusken der Regelsbrunner Au. Abh Zool-Bot Ges Österreich 31:99-124

Weihrauch F (1998) Die Entwicklung von Gomphus vulgatissimus (L.) in Kiesgrubengewassern: seltene Ausnahme oder lediglich ubersehen? (Anisoptera: Gomphidae). Libellula 17:149-161

Wildermuth H, Krebs A (1983) Die Bedeutung von Abbaugebieten aus der Sicht des biologischen Naturschutzes. Beih Veröff Nat schutz Landsch pfl Baden-Württ 37:105-150

Williams P, Whitefield M, Biggs J, Bray S, Fox G, Nicolet P, Sear D (2004) Comparative biodiversity of rivers, streams, ditches and ponds in an agricultural landscape in Southern England. Biol Conserv 115:329-341. doi:10.1016/S0006-3207(03)00153-8

Wimmer W, Sprick P (2000) Records of Weevils (Coleoptera: Curculionidae) on Myriophyllum species, with special regard to M. heterophyllum Michaux, in Lower Saxony, Germany. Braunsch Nat kdl Schr 6:123-130

Winfield Fairchild G, Faulds AM, Matta JF (2000) Beetle assemblages in ponds: effects of habitat and site age. Freshw Biol 44:523-534. doi:10.1046/j.1365-2427.2000.00601.x

Xylander WER (1999) Libellen (Insecta:Odonata) der Grube Fernie, einer ehemaligen Mangangrube bei Linden Hessen. Chionea 15:5-18 